\title{
Origin and fate of dissolved organic matter in four shallow Baltic Sea estuaries
}

\author{
Maren Voss (i) Eero Asmala • Ines Bartl · Jacob Carstensen • Daniel J. Conley • \\ Joachim W. Dippner • Christoph Humborg • Kaarina Lukkari • \\ Jolita Petkuviene - Heather Reader • Colin Stedmon • Irma Vybernaite-Lubiene • \\ Nicola Wannicke $\cdot$ Mindaugas Zilius
}

Received: 19 March 2020/ Accepted: 18 September 2020/Published online: 15 October 2020

(C) The Author(s) 2020

\begin{abstract}
Coastal waters have strong gradients in dissolved organic matter (DOM) quantity and characteristics, originating from terrestrial inputs and autochthonous production. Enclosed seas with high freshwater input therefore experience high DOM concentrations and gradients from freshwater sources to more saline waters. The brackish Baltic Sea experiences such salinity gradients from east to west and from river mouths to the open sea. Furthermore, the catchment areas of the Baltic Sea are very diverse
\end{abstract}

Responsible Editor: Robert W. Howarth.

This paper is an invited contribution to the 35th Anniversary Special Issue, edited by Sujay Kaushal, Robert Howarth, and Kate Lajtha.

Electronic supplementary material The online version of this article (https://doi.org/10.1007/s10533-020-00703-5) contains supplementary material, which is available to authorized users.

M. Voss $(\bowtie)$ - I. Bartl · J. W. Dippner · N. Wannicke

Biological Oceanography, Leibniz Institute for Baltic Sea

Research, Warnemünde, Germany

e-mail: maren.voss@io-warnemuende.de

E. Asmala

Tvärminne Zoological Station, University of Helsinki,

Hanko, Finland

J. Carstensen

Department of Bioscience, Aarhus University, Roskilde,

Denmark and vary from sparsely populated northern areas to densely populated southern zones. Coastal systems vary from enclosed or open bays, estuaries, fjords, archipelagos and lagoons where the residence time of DOM at these sites varies and may control the extent to which organic matter is biologically, chemically or physically modified or simply diluted with transport off-shore. Data of DOM with simultaneous measurements of dissolved organic (DO) nitrogen $(\mathrm{N})$, carbon (C) and phosphorus (P) across a range of contrasting coastal systems are scarce. Here we present data from the Roskilde Fjord, Vistula and Öre estuaries and Curonian Lagoon; four coastal systems with large differences in salinity, nutrient concentrations, freshwater inflow and catchment characteristics. The C:N:P ratios of DOM of our data, despite high variability, show site specific significant differences resulting largely from differences residence time. Microbial

\author{
D. J. Conley \\ Department of Geology, Lund University, Lund, Sweden \\ C. Humborg \\ Stockholms Universitets Östersjöcentrum, Stockholm, \\ Sweden \\ K. Lukkari \\ Finnish Environment Institute, Marine Research Centre, \\ Agnes Sjöbergin katu 2, 00790 Helsinki, Finland
}


processes seemed to have minor effects, and only in spring did uptake of DON in the Vistula and Öre estuaries take place and not at the other sites or seasons. Resuspension from sediments impacts bottom waters and the entire shallow water column in the Curonian Lagoon. Finally, our data combined with published data show that land use in the catchments seems to impact the DOC:DON and DOC:DOP ratios of the tributaries most.

Keywords Coastal systems - Dissolved organic matter $\cdot$ Riverine input $\cdot$ Baltic Sea

\section{Introduction}

Dissolved organic matter (DOM) constitutes a significantly larger reservoir than particulate organic matter (POM) in the ocean and these fractions have differing roles as the latter is rapidly removed due to sinking whereas DOM is advected and widely distributed. DOM is a mixture of compounds of diverse complexity including carbon $(\mathrm{C})$, nitrogen $(\mathrm{N})$, and phosphorus (P) in proportions that deviate from POM. On average oceanic POM has ratios of $\mathrm{C}: \mathrm{P}, \mathrm{N}: \mathrm{P}$, and $\mathrm{C}: \mathrm{N}$ of 163 , 22, and 6.6, and the classical Redfield C:N:P ratio of $106: 16: 1$ is only met in upwelling regions (Martiny et al. 2014). The DOM pool is everywhere much richer in $\mathrm{C}$ and $\mathrm{N}$ compared to $\mathrm{P}$ and has an average ratio of 810:48:1 (Letscher and Moore 2015). The reason for the pronounced difference in elemental composition of particulate and dissolved pools is believed to be due to the selective degradation of more labile $\mathrm{N}$ - and

J. Petkuviene $\cdot$ I. Vybernaite-Lubiene $\cdot$ M. Zilius Marine Research Institute, Klaipeda University, Universiteto al, 17, 92295 Klaipeda, Lithuania

\section{H. Reader}

Department of Chemistry, Memorial University of Newfoundland, St. John's, Canada

C. Stedmon

National Institute of Aquatic Resources, Technical University of Denmark, Building 202, Kemitorvet, 2800 Kgs Lyngby, Denmark

Present Address:

N. Wannicke

Leibniz Institute für Plasmaforschung und Technologie e.V., Greifswald, Germany
P-rich components such that carbon accumulates in molecules of decreased bioavailability, molecular size and energetic content (Benner and Amon 2015; Aminot and Kérouel 2004).

Allochthonous and autochthonous sources of DOM differ in stoichiometry, as soil-derived organic matter supplied by rivers is typically more carbon rich with higher C:N ratios (Mattson et al. 2005) compared to DOM produced by phytoplankton (Lønborg et al. 2009a). Fundamental differences in the biochemical composition of terrestrial and aquatic plants as well as microbial processing of organic matter in soils vs. water are the main reason for this discrepancy. As DOM is a complex mixture of potentially thousands of individual chemical compounds, it can be seen to be comprised of multiple pools with differing bioavailability and reactivity towards microbial breakdown (Lønborg and Álvarez-Salgado 2012; Wilson and Xenopoulos 2009). In fact, in the Baltic Sea and especially in the estuaries DOM is mainly of terrestrial origin and for the open basins the contribution of terrestrial DOM to the total pool of DOM has been estimated to be between 43 and 83\% (Deutsch et al. 2012). In disturbed catchments with high percentages of intense cultivation and little forested area the DOM exported to streams may be less complex (Wilson and Xenopoulos 2009). DON and DOP export increases with cultivated land and is related to fertilizer and manure use in the catchments (Seitzinger et al. 2002; Stedmon et al. 2006). On the other hand, catchments with a high population density were found to be related to an increasing age of DOC caused by the mobilization of aged carbon (Butman et al. 2015).

Here we have studied the composition of DOM in four different estuaries of the Baltic Sea. The sea is characterized by an east-west salinity gradient from $<3$ in northern Bothnian Bay and eastern Gulf of Finland to over 20 in the Kattegat. Surface DOM measured along this gradient is apparently relatively invariant in its molecular composition, and the highly resolved molecular data identify only differences in DOM characteristics in sulfidic deep waters (Seidel et al. 2017). In contrast along the extensive Baltic coastline DOM composition may strongly differ due to dilution variability in freshwater mixing zones ranging from traditional salt wedge estuaries, to coastal lagoons, to fjords or embayments (Asmala et al. 2017). Secondly, from differences in riverine inputs of inorganic nutrient and organic matter which vary from 
south to north. The major southern rivers like Nemunas and Vistula primarily drain cultivated land with relatively high nitrogen and phosphorus concentrations while the boreal northern catchments are consisting of forests, mires, streams and lakes where nutrient delivery is low and DOM loads are high (Voss et al. 2006).

When river water enters the coastal zone nutrients and DOM are either consumed by phytoplankton and heterotrophic bacteria or undergoes dilution by mixing with seawater with lower nutrient concentrations depending on load and season (Ferguson et al. 2004). Photodegradation and flocculation may also play a role for the degradation of DOM (Gustafsson et al. 2000). The longer a water mass remains within a coastal ecosystem, the higher the proportion of land-derived nutrient consumption by phytoplankton that leads to the production of autochthonous DOM (Dippner et al. 2019). When a freshwater bulge is formed the water can remain for or up to 9 days near the coast as shown for the Gulf of Riga (Soosaar et al. 2016) or when an eddy develops water in the Vistula estuary remains up to 1 week (Voss et al. 2005). This time should allow for a higher degradation of DOP components, while the degradation of DON and DOC is slower, leading to a shift in the ratios over time (Lønborg et al. 2009b).

Few studies have presented data on the three main elements C, N and P in DOM in the Baltic Sea and only 5 studies out of 35 had data for all the three main DOM constituent (DOC, DON, and DOP) in the review by (Hoikkala et al. 2015). In this study, we have collected data on DOC, DON, and DOP from four representative coastal sites across a large range of latitudes of the Baltic Sea; one lagoon, and three estuaries with large differences in residence times, nutrients, and DOM inputs (Fig. 1, Table 1). Our site selection allows a crosssystem comparison under a wide range of hydrological and environmental situations to test the hypothesis that rivers act as characteristic DOM source-depending on land use in the catchment—which is modified along a salinity gradient from the river offshore.

\section{Materials and methods}

Sampling sites and tributaries

Two major (Vistula and Nemunas River) and several minor tributaries (including Öre River) to the Baltic
Sea and the four corresponding coastal sites have been sampled. The sites differ in terms of geographical location, river flow, dissolved inorganic nitrogen (DIN) — and phosphate (DIP) -load, salinity, topography and water residence time (Fig. 1, Table 1) and reflect the variety of coastal conditions around the Baltic Sea. The Öre Estuary in the northern Baltic Sea receives proportionally little inorganic nutrient input and high DOM during the high flow season in May/ June. The Vistula River load, in contrast, is dominated by inorganic nitrogen with maximum loads in February-April that drain into the Bay of Gdansk. The Curonian Lagoon receives input from the eutrophic Nemunas River with maximum drainage in February/ March, and waters remain in the lagoon for an extended period of time. Numerous small streams drain into the Roskilde Fjord which is surrounded primarily by agricultural land (Asmala et al. 2018a, b). The residence time in the four coastal systems varies from 9 days in the Öre estuary to up to 8 months in the Roskilde Fjord (Table 1). Land use differs with just $2 \%$ of cultivated land in the Öre River catchment and up to $49 \%$ in the Vistula River and $66 \%$ for the Danish catchments, forests vary from 12 to $65 \%$ (UNECE 2011).

Sampling and analysis

Samples collected during a series of field campaigns by different research groups around the Baltic Sea (Fig. 1) in 2014-2017 (Carstensen et al. 2020), were analysed with comparable internationally standardized methods, although with slight deviations among sites (Table 2). Most DOC and DON were measured at the Technical University of Denmark, except samples from the Curonian Lagoon were measured at Klaipeda University, and DON samples from Vistula and Öre estuaries at the IOW. The pre-filtration was in most cases done with $0.2 \mu \mathrm{m}$ filters but sometimes $\mathrm{GF} / \mathrm{F}$ filters with a nominal pore size of $0.7 \mu \mathrm{m}$ were used. In light of the detection limits of the analyses and the small volumes analysed, this will not lead to significant differences in DOC, DON, or DOP. DOC at both the Technical University of Denmark and Klaipeda University was measured using catalytic high-temperature combustion (Shimadzu TOC V-CPH). At each site DON and DOP were determined as the difference of the total dissolved $\mathrm{N}$ and $\mathrm{P}$ (TDN, TDP) and dissolved inorganic $\mathrm{N}$ and $\mathrm{P}$ (DIN, DIP) fractions. 
Fig. 1 Map of the Baltic Sea indicating the locations of the four study sites. These are enlarged with the tributaries in blue: in Roskilde Fjord several small tributaries, in Vistula Estuary the Vistula River, in the Curonian Lagoon the Nemunas River and in Öre Estuary the Öre River

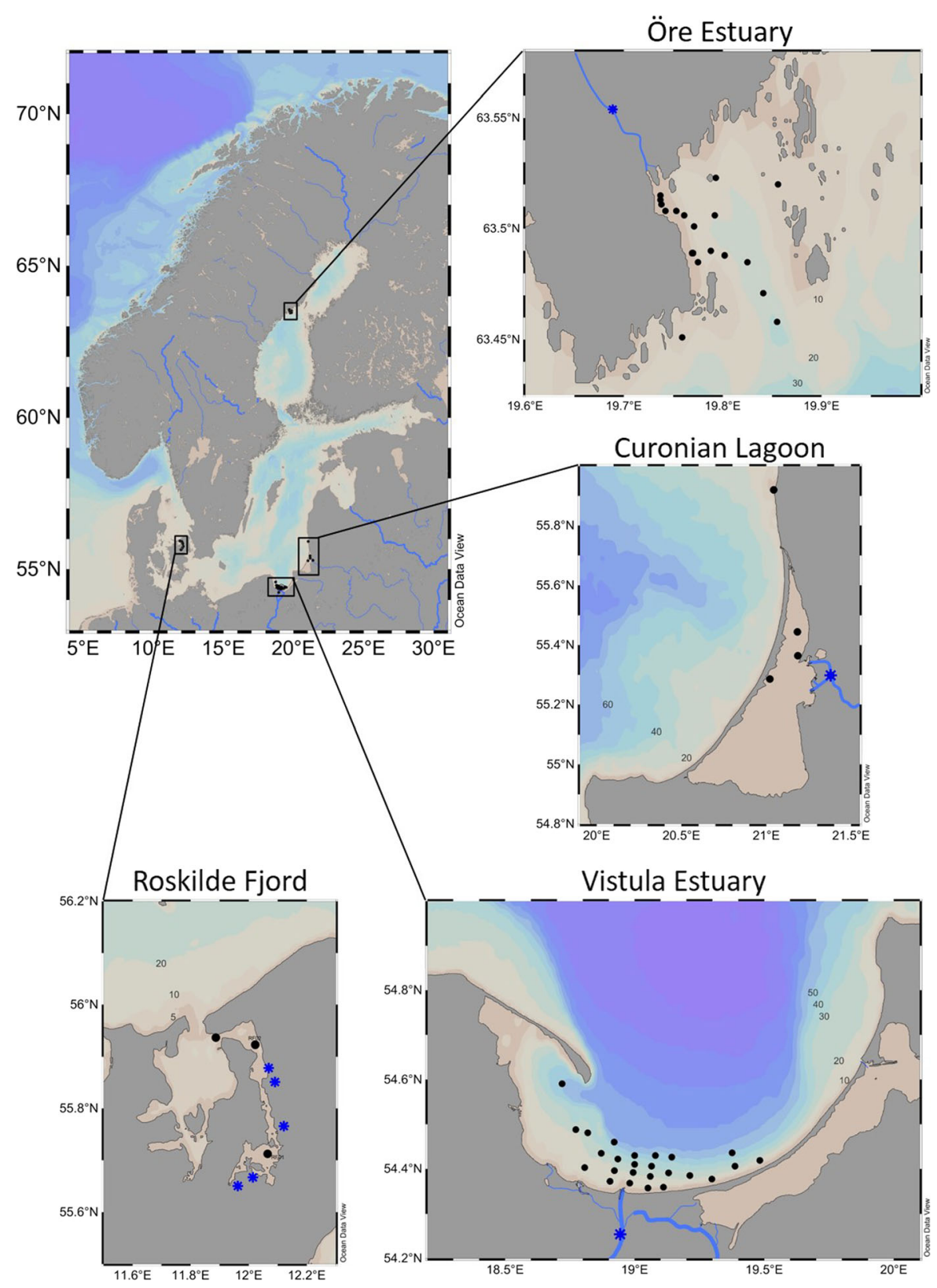

TDN was either determined by catalytic high-temperature combustion with chemiluminescence detection or persulfate digestion and subsequent nitrate analysis (Koroleff 1983). TDP was measured using persulfate digestion and subsequent phosphate analysis (Koroleff 1983). Dissolved inorganic nitrogen (nitrate, nitrite, and ammonium) and phosphate were measured with a Quattro Autoanalyser in Vistula and Öre estuaries, continuous flow analyser Skalar $\mathrm{San}^{++}$in the Curonian Lagoon, and with a Lachet QuikChem FIA +8000 in Roskilde Fjord (methods after Grasshoff et al. 1999). The analytical error is $<0.1 \mu \mathrm{mol} \mathrm{L} \mathrm{L}^{-1}$ 
Table 1 Characteristics of the study sites, small superscripts indicate the source of the data ${ }^{1)}$ (Pedersen et al. 2014), ${ }^{2)}$ (HELCOM 2018), ${ }^{3)}$ public web page: http://miljodata.slu.se/ mvm/, ${ }^{4)}$ (Dippner et al. 2019), ${ }^{5)}$ (Asmala et al. 2018b)

${ }^{6)}$ (Umgiesser et al. 2016; Zilius et al. 2018) ${ }^{7)}$ (UNECE 2011)

${ }^{8)}$ Statistical Yearbook (2006)

\begin{tabular}{|c|c|c|c|c|}
\hline & $\begin{array}{l}\text { Roskilde Fjord } \\
\text { RF }\end{array}$ & $\begin{array}{l}\text { Vistula Estuary } \\
\text { VE }\end{array}$ & $\begin{array}{l}\text { Öre Estuary }{ }^{3)} \\
\text { ÖE }\end{array}$ & Curonian Lagoon CL \\
\hline \multicolumn{5}{|l|}{ General site description } \\
\hline Type & $\begin{array}{l}\text { Narrow fjord with } 5 \\
\text { streams }\end{array}$ & $\begin{array}{l}\text { Wide bay with Vistula } \\
\text { River }\end{array}$ & $\begin{array}{l}\text { Small basin with Öre } \\
\text { River }\end{array}$ & $\begin{array}{l}\text { Lagoon with Nemunas } \\
\text { River }\end{array}$ \\
\hline Residence time & $3-8$ months $^{5)}$ & $35-60$ days $^{4)}$ & 9 days ${ }^{3)}$ & 3 months $^{6)}$ \\
\hline River load TN (kt year ${ }^{-1}$ ) & $1.69^{1)}$ & $65^{2)}$ & $0.45^{3)}$ & $32^{2)}$ \\
\hline River load TP $\left(\mathrm{kt} \mathrm{y}^{-1}\right)$ & $0.01^{1)}$ & $7.9^{2)}$ & $0.03^{3)}$ & $1.1^{2)}$ \\
\hline Average depth (m) & $3-4$ & 29 & 10 & 3.8 \\
\hline $\begin{array}{l}\text { Surface area of the lagoon/ } \\
\text { bay }\left(\mathrm{km}^{2}\right)\end{array}$ & 74 & 825 & 71 & 1584 \\
\hline Catchment area $\left(\mathrm{km}^{2}\right)$ & Unknown & $194,424^{7)}$ & $3045^{7)}$ & $97,864^{7)}$ \\
\hline Land use & $\begin{array}{l}66 \% \text { cultivated } \\
12 \% \text { forests }^{8)}\end{array}$ & $\begin{array}{l}49 \% \text { cultivated } \\
38 \% \text { forests }^{7)}\end{array}$ & $\begin{array}{l}2 \% \text { cultivated } \\
65 \% \text { forest }^{3)}\end{array}$ & $\begin{array}{l}39 \% \text { cultivated } \\
46 \% \text { forest }^{7)}\end{array}$ \\
\hline \multicolumn{5}{|c|}{ Annual mean concentrations in rivers draining into the respective coastal sites (n) } \\
\hline DOC $\left(\mu \mathrm{mol} \mathrm{L}{ }^{-1}\right)$ & $719 \pm 141(80)$ & $560(1)$ & $775 \pm 350$ & $586 \pm 140(6)$ \\
\hline $\mathrm{DON}\left(\mu \mathrm{mol} \mathrm{L}{ }^{-1}\right)$ & $34 \pm 29(29)$ & $60(1)$ & $19 \pm 14(3)$ & $27 \pm 12(6)$ \\
\hline $\mathrm{DOP}\left(\mu \mathrm{mol} \mathrm{L}^{-1}\right)$ & $1.4 \pm 3.3(29)$ & $0.4(1)$ & $0.1 \pm 0.1(2)$ & $0.5 \pm 0.6(6)$ \\
\hline
\end{tabular}

for all nutrients measured. Below only the sitespecific sampling and unpublished analytical details are given.

\section{Roskilde Fjord}

Details of the field sampling and DOM analyses are described in Asmala et al. (2018a, b). In summary, three estuarine and five stream stations in Roskilde Fjord were sampled on 22 occasions between May 2014 and November 2015. Stream samples were taken from the surface only whereas estuarine water was sampled from two depths, one and four meters at each site. After collection, samples from the water column were kept cold and in the dark before filtering in the laboratory within $6 \mathrm{~h}$ after sampling.

\section{Vistula Estuary}

Three cruises were carried out in the Vistula Estuary (R/V Elisabeth Mann Borgese, EMB077 in July 2014, R/V Alkor, AL449, in early February 2015, and EMB123 in Feb/March 2016). In summer 2014 samples from 4 to 7 water depths from 12 stations were collected of which five bottom water samples were collected for DOM analyses. In winter 2015 samples from 4 to 8 water depths from 13 stations, and in spring 2016 1-8 water depths from 18 stations were collected. All water samples were taken using a seabird 911 + CTD-system with $5 \mathrm{~L}$ water bottle rosette. Near-bottom water samples were additionally taken from the undisturbed water above the sediment collected with a multicorer. River water was collected a few kilometers upstream on a bridge at two occasions (February and July) and kept cold and dark until processing of the water on board.

For TDN filtered water (precombusted GF/F) was collected in acid washed and precombusted 50-mLglass vials and frozen at $-20{ }^{\circ} \mathrm{C}$. Analysis followed the persulfate oxidation method (Koroleff 1983) performed in a microwave (MarsXpress, CEM) at $180{ }^{\circ} \mathrm{C}$ for $50 \mathrm{~min}$. EDTA standards were used to check for complete conversion to nitrate, which was then determined using spongy cadmium (Jones 1984). The oxidation efficiency ranged from 90 to $110 \%$. DON was calculated as the difference of TDN and DIN. TP and DOP was determined as described for the Öre Estuary. POM was collected on precombusted GF/F filters, filters were dried, and analysed with a Thermo Fisher Scientific Elemental Analyser 


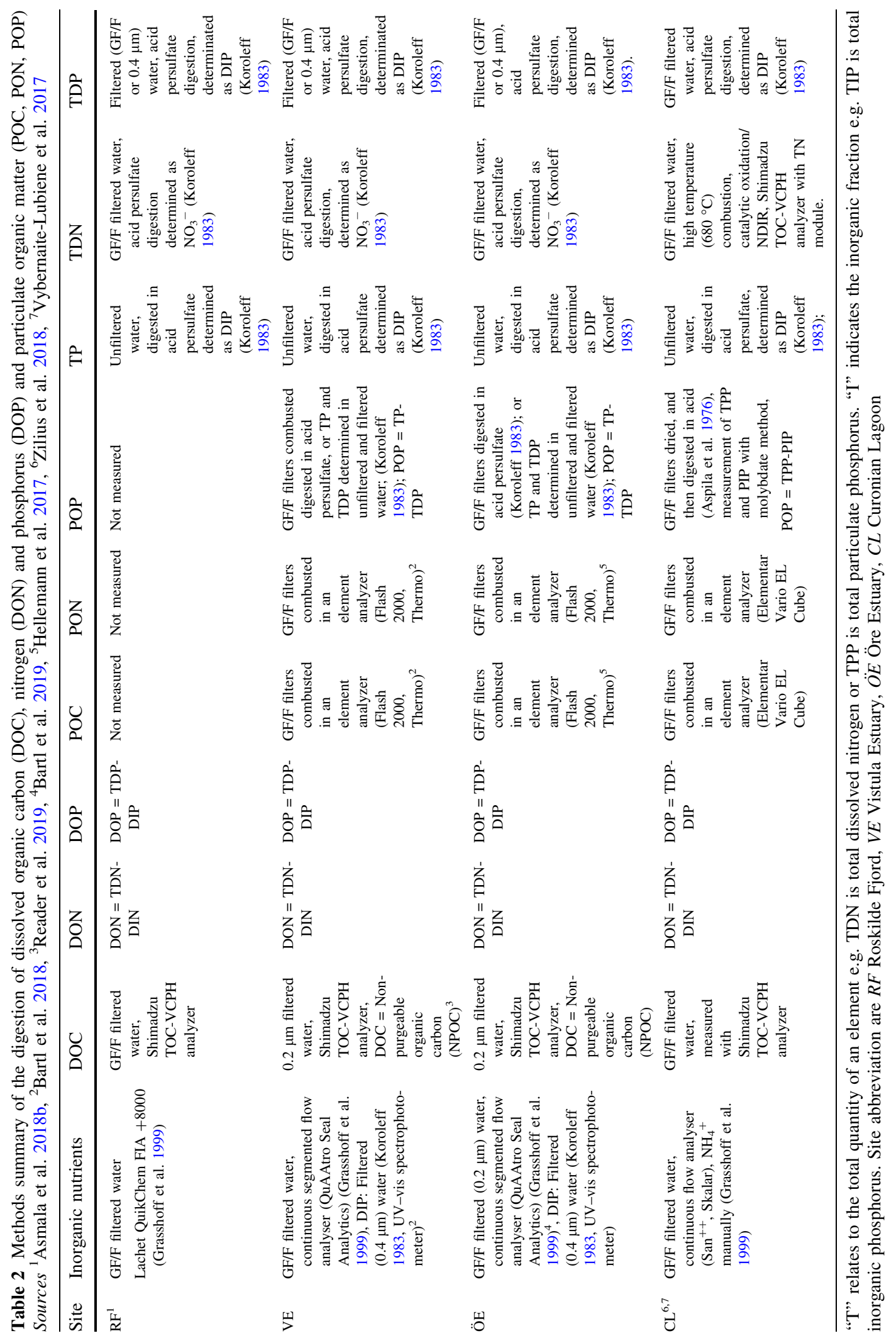


connected to an isotope-ratio mass spectrometer. Calibration was done with acetanilide (Merck) and internal peptone standard (details in Bartl et al. 2018).

\section{Öre Estuary}

Samples from 13 and 14 stations were taken during two field campaigns in April and August 2015, respectively. The stations covered the entire plume of the Öre River, the river, and the sediments. Temperature and conductivity were measured with a Seabird SBE 19 plus system. Chlorophyll fluorescence, organic matter fluorescence, turbidity and dissolved oxygen were measured using a Seaguard CTD (Aanderaa). Water samples for water chemistry were collected using a GoFlo Niskin bottle. Nearbottom water samples were additionally taken from the undisturbed water above the sediment collected with a Gemini corer (muddy sediments) or a HAPs sampler (KC Denmark) for sandy sediments. Samples were kept cold until further processing within $3 \mathrm{~h}$ of sampling. TDP concentrations in the filtered samples were determined using an UV/VIS spectrophotometer (Genesys 10S UV-Vis, Thermo Fisher Scientific; detection limit $0.05 \mu \mathrm{mol} \mathrm{L}^{-1}$ ) as DIP after acid persulphate oxidation (Koroleff 1983) and the DOP concentration was calculated subtracting DIP from TDP. POM and DOM was collected and processed as described above for the Vistula Estuary (details in Hellemann et al. 2017).

\section{Curonian Lagoon}

Seasonal samples were collected from 2014 to 2015 at 3 sites, representing transitional, riverine flushed and accumulation areas (1.5-3.5 m depth) in the Curonian Lagoon. Water samples ( $2 \mathrm{~L})$ at each site were collected in triplicate from surface and bottom layers with a Ruttner bottle, later transferred to opaque HDPE (Nalgene ${ }^{\circledR}$ ) bottles and transported with ice packs to the laboratory within two hours for further treatment (Vybernaite-Lubiene et al. 2017). In addition, water temperature, salinity and dissolved oxygen were measured in situ at the surface $(0.5 \mathrm{~m}$ depth $)$ and bottom $(0.5 \mathrm{~m}$ above the sediment) using a YSI 460 probe.
Statistics and calculations

Prior to all data analysis, DOM and POM were checked for outliers. Observations larger than six times the normalized standard deviation from the mean were identified as outliers which resulted in the removal of two observations. Near bottom samples in Vistula and Öre estuaries were collected from clear water overlying the sediments but often showed elevated particulate matter concentrations. These data sets were treated separately as bottom boundary layer (BBL) data. Ratios of DOC:DON:DOP and POC:PON:POP were first calculated for each single concentration measurement per depth, site, and season. DOC, DON, DOP values mean and standard deviation per site was calculated as well.

The data was tested for normal distribution before other statistics were applied using both, KolmogorovSmirnov test and Shapiro-Wilks W-test. Differences among sites and season in the DOM data and their ratios in surface and bottom waters, respectively, were investigated using ANOVA (http://www.physics. csbsju.edu/stats/anova.html). Empirical Orthogonal Function (EOF) analysis based on covariance matrices to identify correlations among all measured variables were performed with Statistica ${ }^{\circledR} 6$.

To estimate potential removal of DOM, DIN, or DIP across the salinity gradient of each sampling site, mixing plots of all variables and sites were generated (Liss 1976). As conservative mixing line endmembers for salinity were used; fresh/river water and the most saline endmember. A logarithmic fit was done (using grapher10, Golden Software) for the variables measured at the salinity between endmembers to test for the uptake or release of compounds during the mixing process. Only for the Vistula and Öre estuaries in spring significant deviations from linearity were found for DON and DIN and the losses were quantified by calculation of the area between the line and the logarithmic fit.

\section{Results}

Abiotic variables and inorganic nutrients

Samples from different seasons were collected at all sites but not all seasons were always covered. Therefore, the data were evaluated together 
independent of season but site specific. Salinity (mean and standard variation) varied strongly across sites with lowest in the Curonian Lagoon $(0.23 \pm 0.04)$, followed by Öre Estuary (3.55 \pm 1.34$)$, Vistula Estuary (7.07 \pm 1.2$)$ and the westernmost site, Roskilde Fjord $(17.51 \pm 2.62)$. The peak river flow of the respective tributaries varies and is highest in February/ March for the Vistula Estuary and Curonian Lagoon, in January/February in Roskilde Fjord and in May/ June in the Öre Estuary. The peak river flow lowers the salinity and raises nutrient and potentially chlorophyll concentrations near the river mouths, a feature observed in Vistula estuary and Roskilde Fjord in March and in Öre Estuary in April. Our EOF analysis, however, showed only a few significant relationships between salinity and nutrients concentrations; these were salinity with silica in the Öre Estuary, salinity with phosphate in the Curonian Lagoon and Roskilde Fjord, and salinity with nitrate and silicate in the Vistula Estuary. EOF analysis of Curonian Lagoon data showed negative nutrient, and positive POM and chlorophyll relationships to the temperature.

Nitrate concentrations were the highest in the Vistula Estuary and Curonian Lagoon in winter and spring with single measurements of up to $235 \mu \mathrm{mol} \mathrm{L} \mathrm{L}^{-1}$

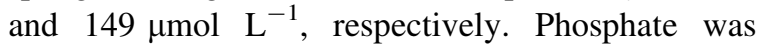
highest in the Roskilde Fjord, followed by the Vistula Estuary and the Curonian Lagoon (Fig. 2). The ratios of DIN:DIP were over 400 near the bottom in the Curonian Lagoon which is twice as high than the maximum ratios at the other study sites where single DIN:DIP ratios varied between 227 and 0.2. Inorganic nutrients in the BBL were in the same range as the waters above (Fig. 2). Silicate concentrations in the Öre and Vistula estuaries when measured at salinities below 1 and were up to $140 \mu \mathrm{mol} \mathrm{L}{ }^{-1}$ and $160 \mu \mathrm{mol} \mathrm{L}-1$, respectively, but the means were much lower with $40.0 \pm 28.8$ and $22.1 \pm 24.6 \mu \mathrm{mol} \mathrm{L}{ }^{-1}$, respectively. No silica data are available from Roskilde Fjord.

Particulate organic matter and Chlorophyll

POM was extremely high in the Curonian Lagoon $\left(388 \pm 226 \mu \mathrm{mol} \mathrm{L}{ }^{-1}\right.$ POC), while Vistula and Öre estuaries had roughly an order of magnitude less POC $\left(32.6 \pm 10.6\right.$ and $29.8 \pm 23.5 \mu \mathrm{mol} \mathrm{L}{ }^{-1}$, Table S1) and the same pattern was found for PON and POP. The BBL samples were significantly higher for Vistula and
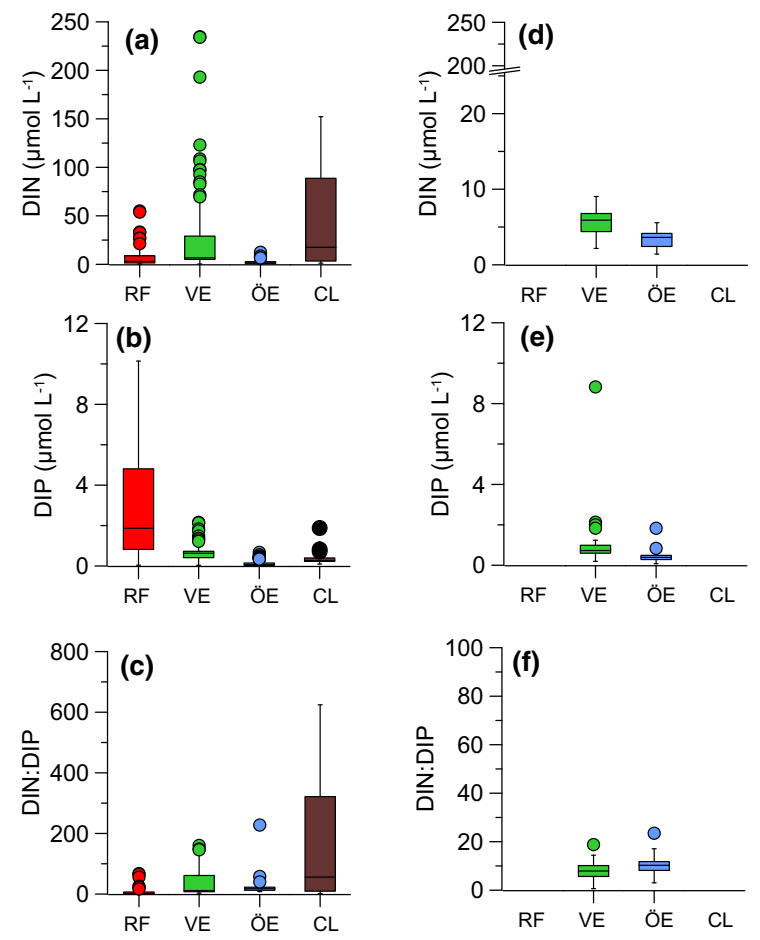

Fig. 2 Box plots of inorganic nutrient data. Colours show the different sampling sites, red: Roskilde Fjord, green: Vistula Estuary, blue: Öre Estuary, and brown: Curonian Lagoon. ac data from the water column above the benthic boundary layer (BBL), $\mathbf{d}-\mathbf{f}$ data from the BBL. Box plots are only shown when data were available. (Color figure online)

Öre estuaries with values of $306 \pm 23$ and $265 \pm 61 \mu \mathrm{mol} \mathrm{L}{ }^{-1}$, respectively (Fig. S1). The mean ratio of POC:PON:POC of the coastal sites was 253:39:1 and much higher than the Redfield Ratio, based on data from all sites but Roskilde Fjord. The chlorophyll concentrations were around $8.7 \pm 6.0$, $3.4 \pm 3.0,3.4 \pm 2.1$ and $43.7 \pm 31.1 \mu \mathrm{g} \mathrm{L^{-1 }}$ for Roskilde Fjord, Vistula, and Öre estuaries, and Curonian Lagoon, respectively with the highest concentrations in spring, except for the Curonian Lagoon where the highest algae concentrations occurred in summer and autumn (up to $157 \mu \mathrm{g} \mathrm{L}^{-1}$ ). The EOF analysis identified correlation for POC and PON over chlorophyll in the Vistula and Öre estuaries and for POM in general in the Curonian Lagoon, while it showed only significant relationships between salinity and chlorophyll concentrations in Öre Estuary. POM was weakly related to any of the nutrient concentrations and salinity was also not a predictor for POM at 
all sites (except Roskilde Fjord where POM was not measured).

\section{Dissolved organic matter}

Based on ANOVA all concentrations of DOM of the four study sites were significantly different (Table 3). The Curonian Lagoon had the highest DOC and DON from all four estuarine systems, while DOP was highest in Roskilde Fjord (Table S1). We found mean surface water DOC between $630-776 \mu \mathrm{mol} \mathrm{L}^{-1}$ in the Curonian Lagoon, and the lowest mean DOC averaged $360 \mu \mathrm{mol} \mathrm{L}^{-1}$ in the Vistula Estuary (Fig. 3). The BBL has the same range of DOC, DON, and DOP at both the Vistula Estuary and Öre Estuary sites where the BBL was sampled separately.

Ratios of DOC:DON, DOC:DOP, and DON:DOP were not significantly different throughout the study sites (Fig. 4) and did not vary with the salinity (except DOC:DON in Roskilde Fjord). The only notable pattern were the consistently low ratios in the BBL that are in the range of the rest of the water column (Fig. 4). Mixing plots of DOC, DON and DOP versus salinity were used to assess whether river derived DOM was diluted and conservatively mixed with increasing salinity (Fig. 5). This was true only for DOC in Roskilde Fjord, Vistula Estuary, and Öre Estuary (Fig. 5). There was no salinity gradient for the

Table 3 Results of ANOVA tests for differences among sites using all except BBL data

\begin{tabular}{lcccl}
\hline Site DOM & Mean & \multicolumn{1}{l}{ Std } & $\mathrm{n}$ & Sign 95\% \\
\hline VE DOC & 318.41 & 33.7 & 161 & No \\
ÖE DOC & 372.16 & 136.0 & 97 & No \\
RF DOC & 463.37 & 90.7 & 67 & No \\
CL DOC & 736.74 & 104.0 & 25 & No \\
VE DON & 14.93 & 4.91 & 122 & No \\
ÖE DON & 14.14 & 1.89 & 79 & No \\
RF DON & 28.63 & 9.73 & 42 & No \\
CL DON & 45.22 & 16.0 & 26 & No \\
VE DOP & 0.26 & 0.005 & 91 & No \\
ÖE DOP & 0.14 & 0.007 & 71 & No \\
RF DOP & 0.38 & 0.32 & 19 & No \\
CL DOP & 0.26 & 0.12 & 25 & No \\
\hline
\end{tabular}

The last column refers to the $95 \%$ significance levels for which no relationships were found
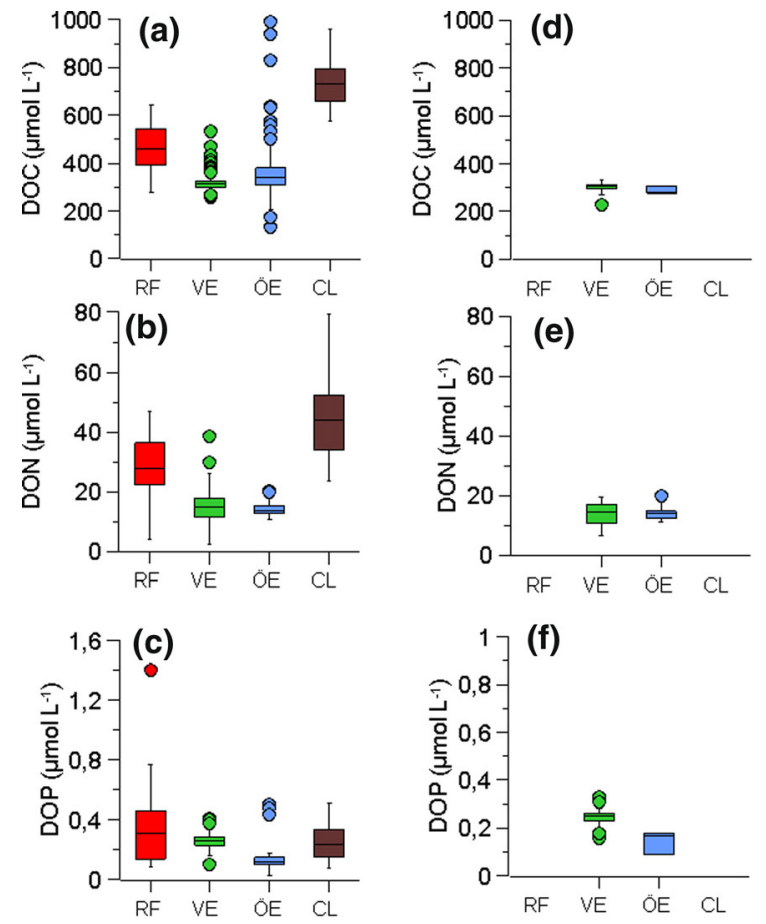

Fig. 3 Box plots of dissolved organic nutrient data. Colors show the different sampling sites, red: Roskilde Fjord, green: Vistula Estuary, blue: Öre Estuary, and brown: Curonian Lagoon. a-c data from the water column above the benthic boundary layer (BBL), d-f data from the BBL. Box plots are only shown when data were available. (Color figure online)

samples from the Curonian Lagoon, because all salinities were around 0.2 .

A comparison of all 221 data points, shows that the concentrations cover a large range from 100 to almost $1000 \mu \mathrm{mol} \mathrm{L}^{-1}$ for DOC, 2.5 to $80 \mu \mathrm{mol} \mathrm{L}^{-1}$ for DON and 0.03 to $1.4 \mu \mathrm{mol} \mathrm{L}{ }^{-1}$ for DOP (Fig. 6, Table 4). Across all seasons, the concentrations from the Öre and Vistula estuaries are the lowest and the Curonian Lagoon the highest. Comparisons of the ratios with the Redfield ratio, the mean ratio of marine DOM and riverine DOM of Baltic rivers reveals interesting patterns (Fig. 6a-c). DOC over DON has a significant slope of 9.1 when all data are evaluated and is different to previously reported river derived DOC:DON (31, Stepanauskas et al. 2002) and closer to marine DOM (16.9, Letscher and Moore 2015, Fig. 6, Table 4). For DOC:DOP and DON:DOP the data are closer to Baltic river DOM, however, with no systematic relationship between concentrations. Plots of the same variables from Baltic rivers are scattered around the straight line 

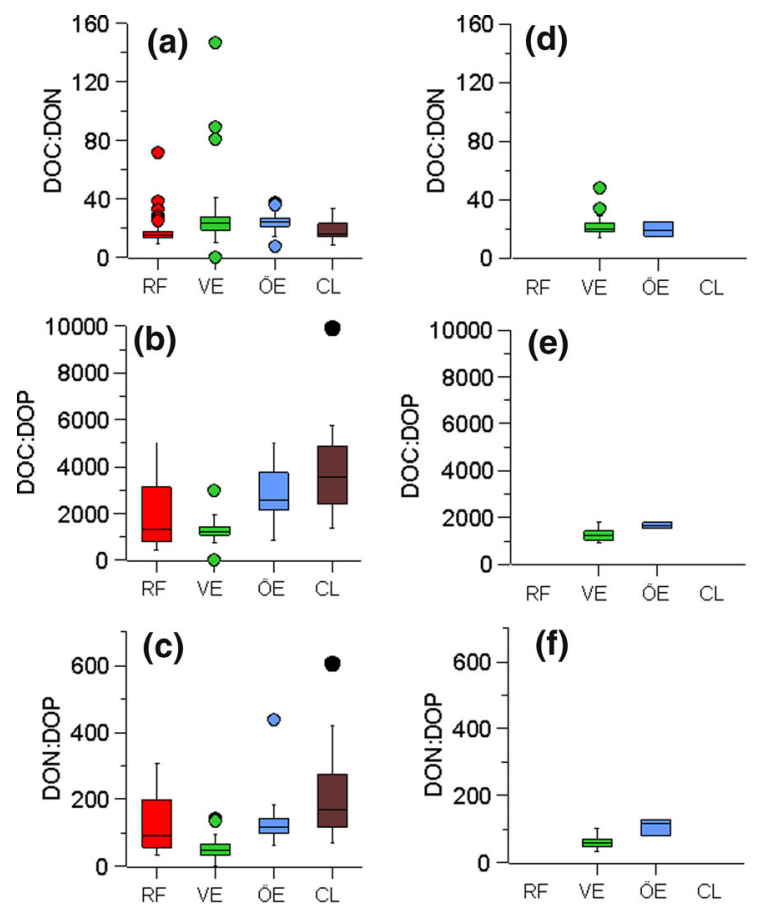

Fig. 4 Box plots of ratios of a DOC:DON, b DOC:DOP, and c DON:DOP. Colors show the different sampling sites, red: Roskilde Fjord, green: Vistula Estuary, blue: Öre Estuary, and brown: Curonian Lagoon. a-c data from the water column above the benthic boundary layer (BBL), d-f data from the BBL. Box plots are only shown when data were available. (Color figure online)

with the slope of Baltic river data from Stepanauskas et al. (2002, Fig. 6d-f).

Land use in the catchments seems to be a major driver of the DOM composition as the ratios over the percentage of cultivated land or forests are all significant on a $\mathrm{p}<0.001$ level (only DOC:DON forest $\mathrm{p}<0.01$ ) and DOC in particular is highest from forest covered land (Fig. 7). The Nordic rivers experience the highest DOC:DON and DOC:DOP ratios of all Baltic rivers and the Öre River aligns well here. The southern rivers are mainly characterised by lower DOC:DON and DOC:DOP ratios and our data from the streams of Roskilde Fjord are similar (no own summertime DOP data of Vistula River). DON:DOP over percentage cultivated land and forest only had a significance of $\mathrm{p}<0.5$ and $<0.2$, respectively. Our riverine data from Nemunas, Öre, Vistula, and Roskilde Fjord tributaries overlap well with data reported from Baltic rivers (Fig. 7).
Finally, we found systematic losses of DIN and DON in Vistula and Öre Estuary in spring through the combination of endmember mixing plots with functions fitted to DIN and DON (Fig. 8). When freshwater input was high, the deviations from conservative behaviour were $8 \mu \mathrm{mol}$ and $265 \mu \mathrm{mol}$ DIN and $29 \mu \mathrm{mol}$ and $126 \mu \mathrm{mol}$ DON for the Öre and Vistula estuaries, respectively. Although the data are only synoptic, they show that during estuarine mixing in spring some removal of DIN and DON occurs.

\section{Discussion}

Relationships between river DOM and land use

Land use impacts the riverine DOM components as the compilation of our data with the data from Stepanauskas et al. (2002) suggests (Fig. 7). Cultivated land that is largely modified by human use seems to release higher concentrations of DON and DOP than forests (Seitzinger et al. 2002; Stedmon et al. 2006), and the DOM C:N:P ratios do show clear trends over the percentage land use in catchments (Fig. 7). Past studies indicate that catchment land use is important in regulating the $\mathrm{C}: \mathrm{N}: \mathrm{P}$ stoichiometry and bioavailability of DOM entering the coastal zone (Stedmon et al. 2006; Markager et al. 2011; Asmala et al. 2013; Reader et al. 2014). For instance, peat soils are a source of carbon-rich and complex humic-like molecules, agricultural lands are sources of relatively labile DOM, while lakes in the catchment can even be sinks for OM (Markager et al. 2011; Mattson et al. 2005; Stedmon et al. 2006; Weyhenmeyer and Conley 2017). DOM from rivers in the northern Baltic Sea is therefore likely less bioavailable than DOM from rivers in the southern Baltic Sea, such as the Nemunas and Vistula rivers that have $39 \%$ and $49 \%$ cultivated land in their catchments (UNECE 2011) and from Roskilde Fjord with its catchment mostly of agricultural land (Asmala et al. 2018b). On the contrary, the Öre River (65\% forest, (UNECE 2011) has higher DOC loads compared to the Vistula and Nemunas rivers and lower DON and DOP. Unfortunately, typical DOM C:N:P ratios of the riverine waters are immediately lost when they mix with coastal waters and their DOM components. 

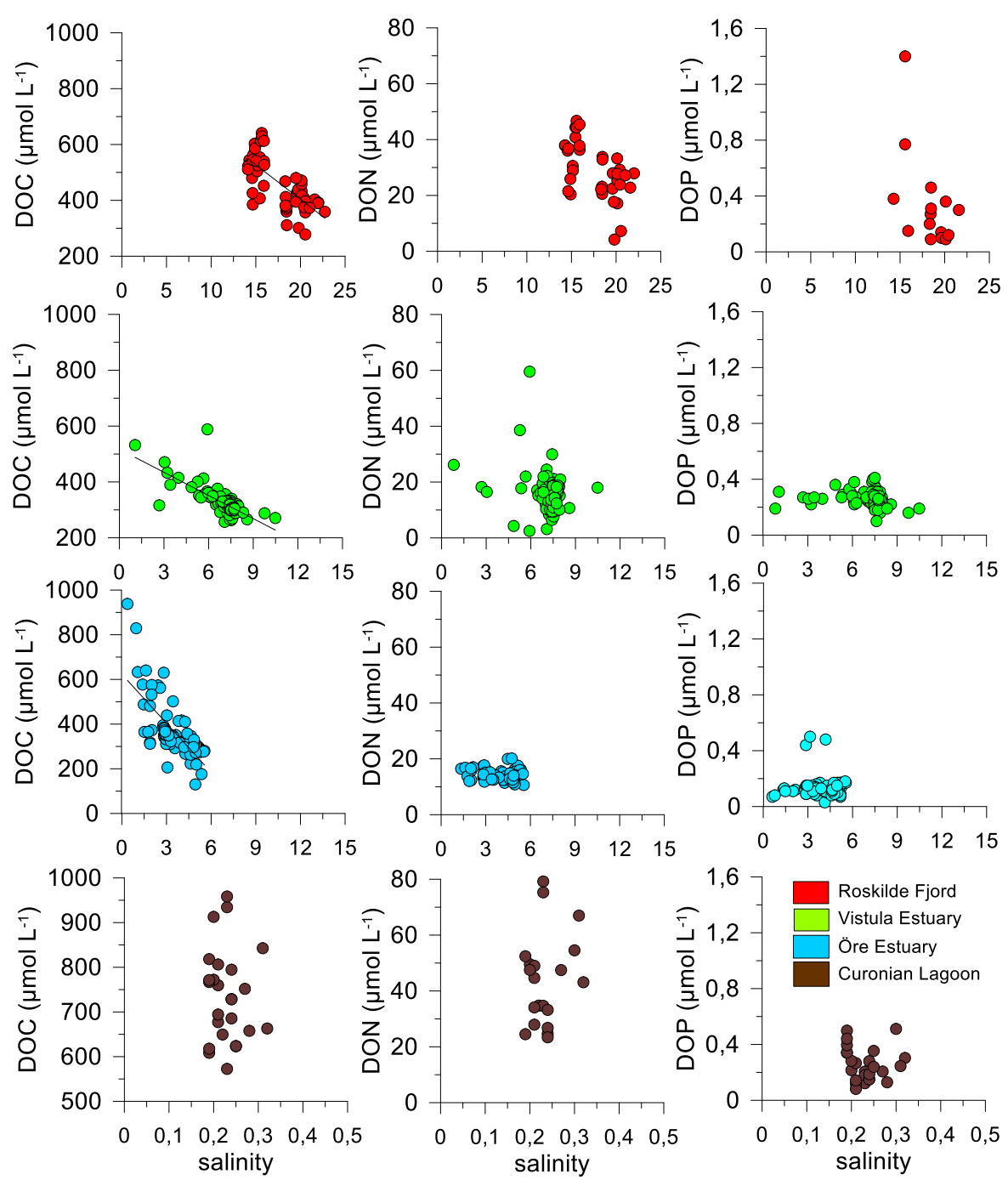

Fig. 5 DOC, DON, and DOP over salinity. Colours show the different sampling sites, red: Roskilde Fjord, green: Vistula Estuary, blue: Öre Estuary, and brown: Curonian Lagoon. Black

\section{Processes in coastal waters}

The strongest changes in $\mathrm{OM}$ concentrations are observed in estuarine gradients from land to sea, and overall in the Baltic Sea from east to west through the major basins. The distinct differences in the morphology and physical properties of the estuarine systems can impact the observed concentrations and they range from (a) a typical salt wedge estuary such as the Öre River in the northern Bothnian Sea, (b) a shallow river impacted lagoon with little marine influence (Curonian Lagoon), (c) the wide and open Bay of Gdansk lines denote significant relationships for DOC $(\mathrm{p}<0.001)$ over salinity in $\operatorname{RF}(\mathrm{n}=54, \mathrm{r}=0.71), \operatorname{VE}(\mathrm{n}=161, \mathrm{r}=0.82)$, and ÖE $(n=90, r=0.72)$. (Color figure online)

with the Vistula River located at the southern coastline (i.e. Vistula estuary), and (d) a narrow Danish fjord with numerous minor streams along its length (Roskilde Fjord). These four sites represent the variety of coastal types of the Baltic Sea, and likely also reflect the broad range of DOM and nutrient inputs as well as their fate in coastal waters.

Furthermore, we anticipated that all components decline with distance from the river source i.e. DOM versus salinity would show a significant negative correlation, and DOP declining faster than DOC and DON (Stepanauskas et al. 2002). Reasons for this 

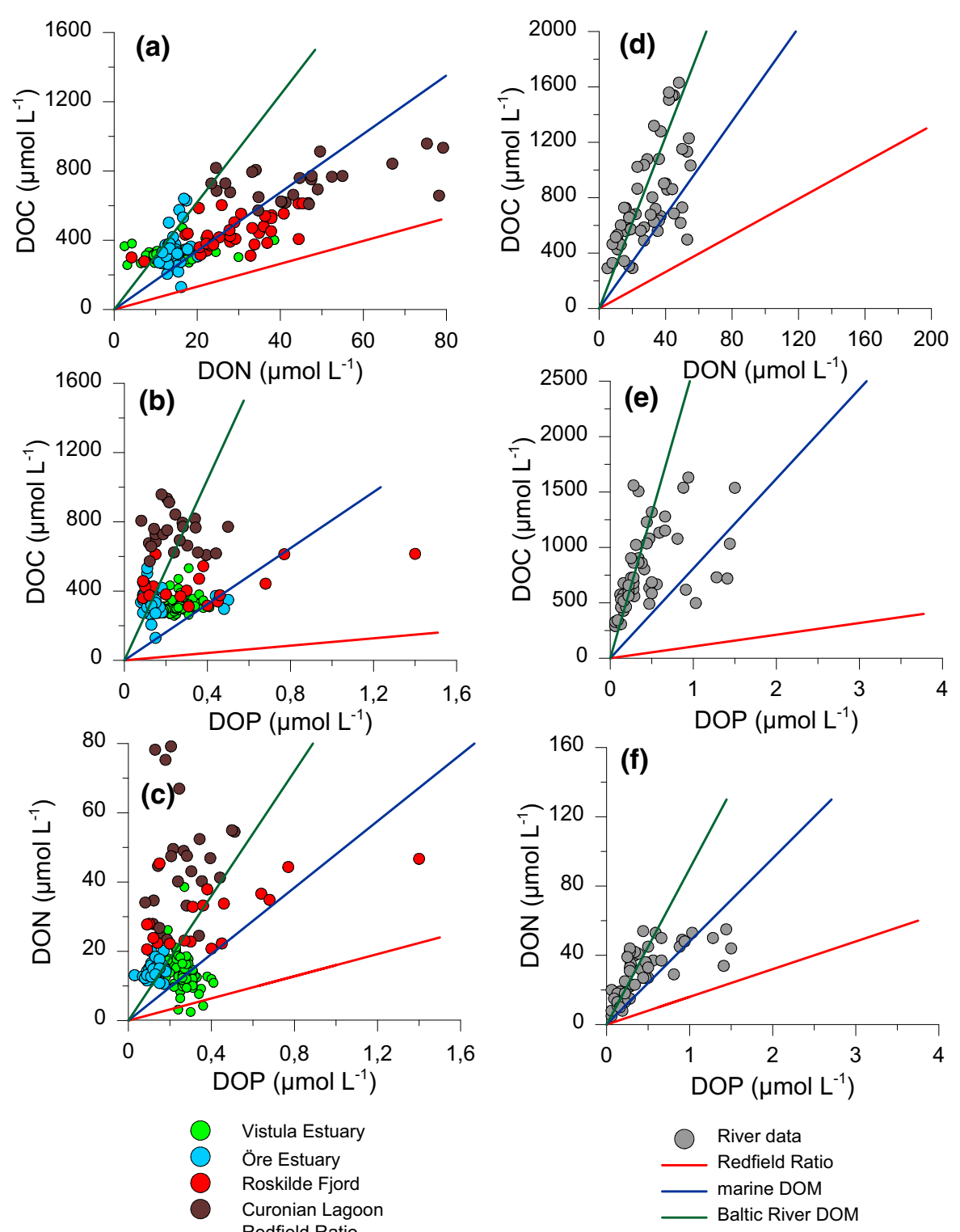

Fig. 6 Ratio plots of a DOC over DON, b DOC over DOP, c DON over DOP of the coastal study sites. The colour code for the sites is the same as in previous figures. Only a has a significant relationship for all estuarine values of DOC over DON: $y=9.10 x+209\left(n=221, r^{2}=0.63, \rho=0.001\right)$. d-

decline should be related cell lysis, which have been shown to be low (Rochelle-Newall and Fisher 2002) or microbial processes (Zweifel et al. 1993). Only DOC followed the expected conservative mixing with differing slopes from each site except for the Curonian

f symbols show river data from Stepanauskas et al. (2002) and own data. The lines denote published ratios taken from Redfield (1963) (Redfield Ratio, red line), Letscher et al. 2015 (Marine DOM, blue line), Stepanauskas et al. 2002 (Baltic river DOM, dark green line). (Color figure online)

Lagoon (Fig. 6a). DON and DOP were not conservatively mixed and may be consumed or produced in that system. If the freshwater end-members of DOC were all included even this may not be conservatively mixed (Asmala et al. 2018b). This also means that nitrogen 
Table 4 Ratios of DOC: DON: DOP normalized to DOP $=1$ for each study site, and from Baltic Sea Rivers ${ }^{1)}$ Stepanauskas et al. (2002), and from the ocean ${ }^{2)}$ Letscher and Moore (2015)

\begin{tabular}{ll}
\hline Location & DOC:DON:DOP ratio \\
\hline RF & $1943 \pm 1444: 128 \pm 89: 1$ \\
VE & $1199 \pm 356: 52 \pm 27: 1$ \\
ÖE & $2661 \pm 981: 113 \pm 25: 1$ \\
CL & $3714 \pm 1854: 221 \pm 127: 1$ \\
DOM Rivers Baltic & 1) \\
Marine DOM $^{2)}$ & $2790: 91: 1$ \\
\hline
\end{tabular}

and phosphorus compounds may have a faster turnover and microbial use as suggested by (Stedmon et al. 2006) and as reported in previous studies for other marine systems e.g., (Clark et al. 1998). Microbial use would lead to deviation below a straight mixing line but this could not be discerned from our data. Instead DON and DOP show a scattered distribution over salinity pointing to a combination of consumption and production in the coastal waters. No production of DIN or DON from remineralisation along salinity gradients was identified. The quantities consumed in Vistula and Öre estuaries were low with only $8 \mu \mathrm{mol}$ and $265 \mu \mathrm{mol}$ DIN and $29 \mu \mathrm{mol}$ and $126 \mu \mathrm{mol}$ DON for Öre and Vistula, respectively, but do not take into account mixing times (Fig. 8). Our calculation was done for the data from spring and cover a time span of approximately one to 2 weeks. Whether the uptake occurred over that time span cannot be discerned but is likely making potential consumption rates very low.

The roles of residence times, resuspension and autochthonous production for DOM in coastal waters

The residence time of the river impacted waters significantly influences the proportion of nutrient and DOM uptake in a water body because the inorganic and organic substances entering the coastal zone are either consumed by phytoplankton and heterotrophic bacteria or undergo dilution by mixing with seawater with lower nutrient concentrations depending on load and season (Ferguson et al. 2004). The longer a water mass remains within a coastal ecosystem, the higher the proportion of nutrient consumption by phytoplankton and production of autochthonous DOM
(Dippner et al. 2019). In a system such as the Curonian Lagoon with its particularly long residence time the high concentrations could be a result of accumulation of substances over time. On the other hand, limited lagoon exchange with Baltic Sea prevents inputs of marine-like DOM, which allows for specific composition of dissolved organic matter. In contrast, waters in the Öre and Vistula estuaries have only short residence times and river loads can rapidly be transported offshore. The time needed for biological or physical processes varies considerably but needs careful consideration to understand the fate of DOM. Over $70 \%$ of DON can be degraded during the first 10 days after river water has been mixed with sea water as experimental work from eutrophic catchments suggests (Seitzinger and Sanders 1997). On the other hand, only $5-10 \%$ of DON originating from rivers draining more pristine and forested catchments in the northern Baltic Sea is degraded in the estuary during the first 2 weeks (Asmala et al. 2013). Degradation rates for DOP are even faster and stimulate primary production (Stepanauskas et al. 2002). Inorganic nutrient uptake by primary producers, subsequent DOM production and its uptake by bacteria occurs in timescales of hours-days (Asmala et al. 2018a; Romera-Castillo et al. 2011) making not only the direct quantification of these processes challenging in the natural environment but also its role in our different study sites. Data from the Roskilde Fjord suggest another fate of nutrients and OM such that autochthonous DOM (produced with the inorganic nutrients from streams) is trapped in a sequence of heterotrophic processes that release processed DOM into waters beyond the estuary (Asmala et al. 2018a). This may be the case at all sites, however with varying quantities of DOM production depending on the residence times at a particular site and season. Our data set suggests a strong relationship between residence time and concentration but also with preferential consumption of DOP resulting in high DOC:DOP and DON:DOP ratios in the sequence Curonian Lagoon, Roskilde Fjord and Öre and Vistula estuaries.

Resuspension and the direct exchange of substances from sediment porewaters into the overlying water can also strongly impact organic and inorganic substance concentrations. A distinct BBL with elevated concentrations of particulate substances were observed throughout the Vistula and Öre estuaries and originate from sedimenting particles from waters above or 

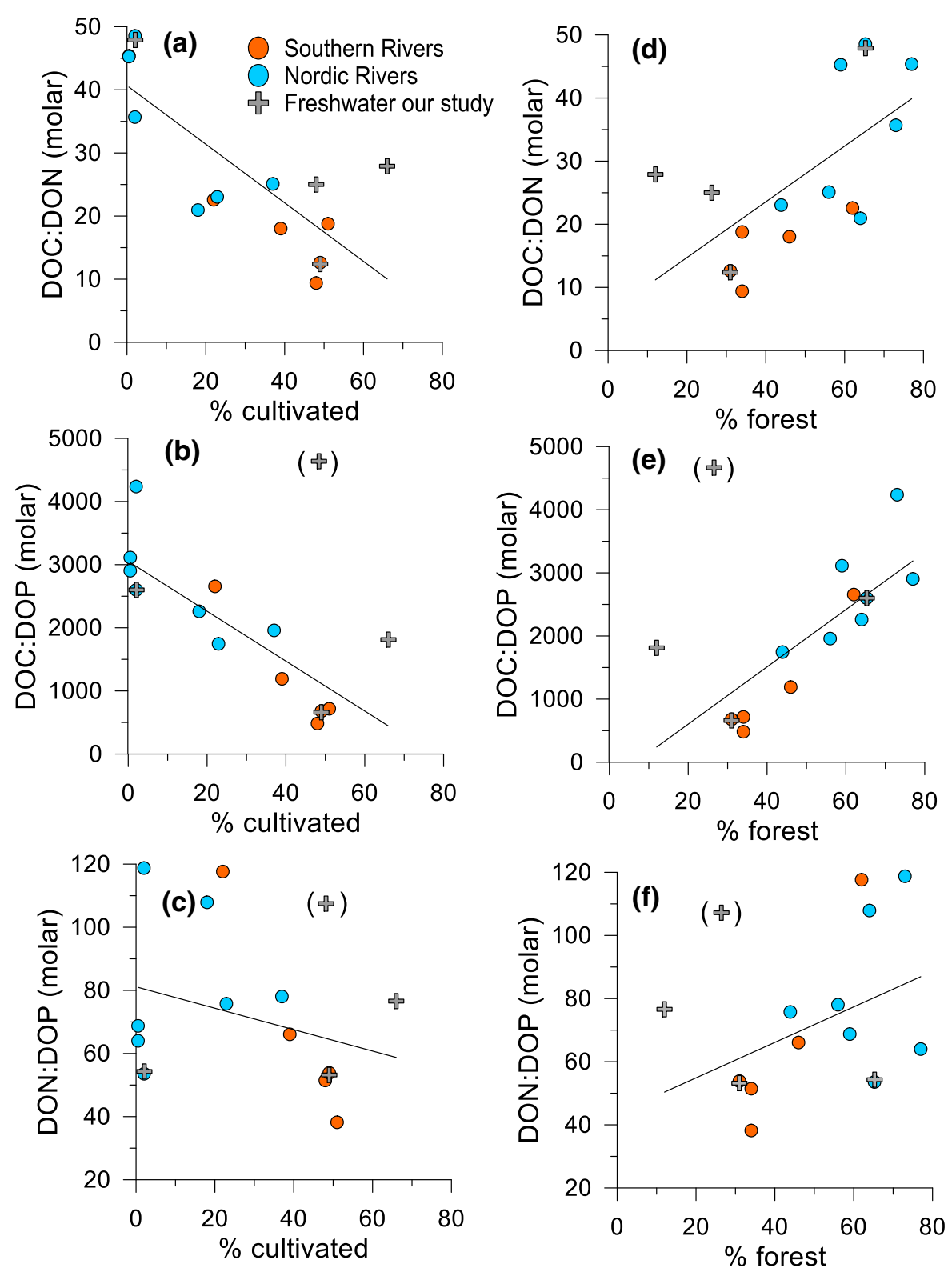

Fig. 7 Ratios of DOM over land use data using the data set of Stepanauskas et al. (2002). a-c DOM ratios over the percentage of cultivated land (data in Table 1), $\mathbf{d}-\mathbf{f}$ DOM ratios over the percentage of forests in the catchments. Blue denotes rivers

draining into the northern Baltic Sea (mainly Swedish and Finnish rivers) and orange shows southern rivers from Germany, Poland, Latvia, Lithuania, and Estonia, grey symbols show data of freshwater endmembers of our study

resuspension (Bartl et al. 2018). Mutual impact of these layers enhance microbial processes such as nitrification and also introduce DOM from sediments into bottom waters (Reader et al. 2019). After a storm in the Vistula Estuary, ammonium from porewaters was microbially processed when the substrate became

available (Happel et al. 2018). In the Curonian Lagoon water column and BBL samples likely indicated fully mixed conditions, while higher concentrations of DIN and DON in summer is a result of resuspension and release of mineralised $\mathrm{N}$ from sediment and recycling in the water (Zilius et al. 2018). 

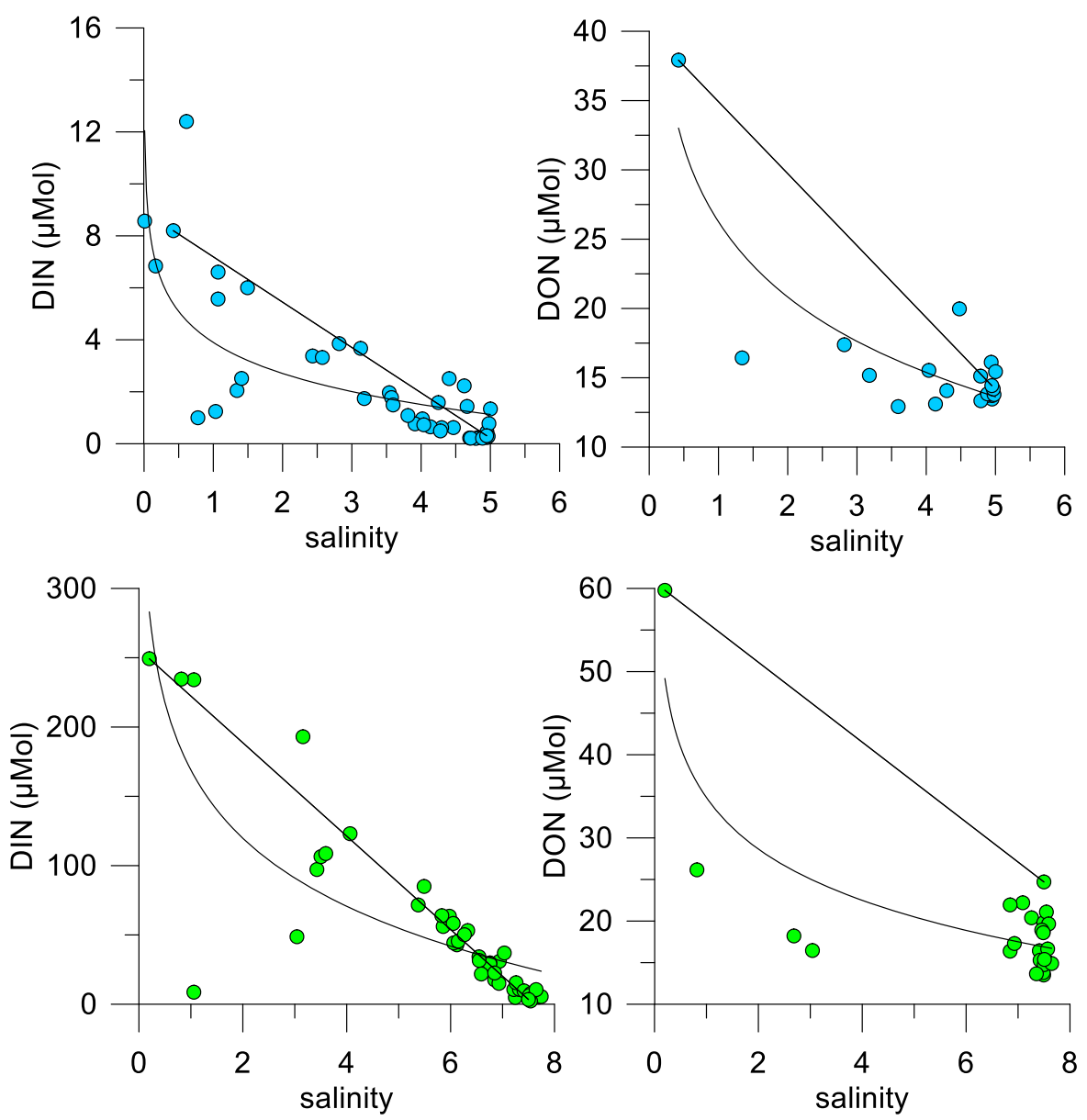

Fig. 8 Mixing diagrams for inorganic and organic nitrogen concentrations over salinity for Öre (blue) and Vistula (green) estuaries in spring. The straight lines denote the theoretical conservative mixing line between endmembers, while the

curved lines represent the best fit to the data, indicating loss of nitrogen species in the estuaries. Only for these data sets meaningful relationships were found

DOP is less variable than DOC and DON at all sites and this differs from findings by Markager et al. (2011) who report higher annual variation over shorter time scales with sampling occurring 1-2 times per month. One possible explanation for the smaller variation in DOP compared to those in DOC and DON is that organic $\mathrm{P}$ compounds, in general, are considered to be mineralized faster than those of $\mathrm{N}$ or $\mathrm{C}$ (BenitezNelson 2000; Clark et al. 1998). In Roskilde Fjord DOP was elevated likely due to remineralisation of $\mathrm{OM}$ in sediments and efficient release from more saline anoxic sediment pore waters (Asmala et al. 2018b), a phenomenon also described for coastal Finish sites (Hoikkala et al. 2012). Part of DOP can be adsorbed onto particle surfaces such as sediment

grains (Ruttenberg and Sulak 2011). This surface reactivity of DOP differs from that of DON and DOC and may partly explain discrepancy in expected consumption-induced changes in DOP levels.

Nutrient dynamics drive the autochthonous production of DOM and were extremely high in the Curonian Lagoon and Vistula Estuary in spring and summer compared to the other sites and corresponds to the supply from the Nemunas and Vistula rivers (Fig. 2, Aleksandrov 2010). These rivers carry the highest and third highest area-specific total $\mathrm{N}$ load of all Baltic Sea rivers, respectively (HELCOM 2018) while the Roskilde Fjord had elevated phosphate concentrations throughout the annual cycle (excluding spring), as a consequence of high terrestrial loading, 
intensive benthic remineralisation (Asmala et al. 2018b) and higher salinities (Blomqvist et al. 2004). DON release by phytoplankton is another likely source of DOM and an important component in the turnover processes. Its bioavailable fractions sustain autotrophic and heterotrophic plankton communities in the coastal environment (Korth et al. 2012; Nausch and Nausch 2011; Stepanauskas et al. 2002). To verify this, we explored relationships between the particulate matter pool and nutrients but for neither site a relationship could be established. A weak indication that particulate matter is related to the growth of phytoplankton was indicated by significant relationships of POM to chlorophyll at all sites (except Roskilde Fjord). The relationship would likely be stronger if only the spring season with maximum river inflow and coastal POM and Chlorophyll would be related (Korth et al. 2012), but the time resolution of our river data in particular is not sufficient. In the Curonian Lagoon, however, the highest POM and chlorophyll a concentrations were encountered during high temperatures and low nutrient concentration which is typical for the recurring cyanobacteria blooms in summer (Zilius et al. 2014).

DOM in the Baltic Sea in comparison to the other seas

The study sites varied widely in many features, most importantly in catchment characteristics and land use. DOM concentrations from the coastal Baltic Sea in this study are roughly an order of magnitude higher compared to major ocean basins. Interestingly, in the open ocean deep water values are largely invariant for DON and DOP compared to DOC indicating continuous changes of carbon compounds versus depth in the deep ocean while nitrogen and phosphorus reach their lowest concentrations (Letscher and Moore 2015). Furthermore, the autochthonous DOM originating from primary production is the dominant DOM source in the open ocean (Letscher et al. 2013). In the Baltic Sea, there is a gradient of source proportions with a high and widespread terrestrial contribution (Seidel et al. 2017) from its catchment, overlaid in the central Baltic Sea with a variable autochthonous DOM production. We assume that the less biodegradable DOC and DON from catchments are responsible for the differences to ocean values. Consequently, a clear sequence in DOM degradation with most available compounds in DOP over DON and DOC as described for the coastal zones in general (Lønborg and ÁlvarezSalgado 2012) could not be confirmed with our data.

\section{Conclusion and outlook}

Our cross system comparison could not identify significant differences in DOM concentrations or elemental ratios across seasons but there were systematic differences across our study sites. The systems all seemed to have different patterns in the DOM concentrations and $\mathrm{C}: \mathrm{N}: \mathrm{P}$ stoichiometry, indicating strong local controls on the DOM biogeochemistry. This finding suggests that the catchment properties and unique features of coastal systems shape the composition and fate of the DOM through multiple processes, e.g. DOM source characteristics, inorganic nutrient availability, freshwater residence time and resuspension of bottom sediments. The type of sediments, whether it is cohesive and thus rich in porewater nutrients compared to permeable low nutrient sediments would then have an impact on DOM and POM composition. Factors such as wave action and bottom type may overprint other features like bioavailable components from catchments.

The Baltic Sea is a suitable test bed for further studies of the processes shaping the DOM pool from land to sea, as there are different gradients in salinity, river chemistry, bathymetry and sediment characteristics; there are lagoons, open bays and stretches from subpolar to continental climate. The apparent lack of relationship between DON and DOP over salinity further points to the important role these low-concentration fractions may play in primary production and heterotrophic microbial processes. Future studies in estuaries combining information about catchment characteristics, sediment quality, estuarine hydromorphology and chemically more accurate identification of specific components of the DOM pool are required to improve our mechanistic understanding about the fate and role of OM in coastal systems.

Acknowledgements Open Access funding enabled and organized by Projekt DEAL. MV was supported by the DFG funded GRK 2000/1 Baltic Transcoast No 35 and IB by BONUS-COCOA funded by the Bundesministerium für Bildung und Forschung (Grant No. 03F0683A), EA was supported by the Academy of Finland (Grant No. 309748), and KL was supported by BONUS COCOA project and the Academy of Finland. HR and CS were supported by 
BONUS-COCOA funded by the Danish Research Council for Independent Research (DFF-1323-00336). DJC was funded by the BONUS COCOA project (Grant \#2112932-1), funded jointly by the European Union and Swedish Research Council for Environment, Agricultural Sciences and Spatial Planning (FORMAS). We like to thank two anonymous reviewers whose suggestions greatly improved the manuscript.

Author contributions All authors contributed to the study conception and design. Material preparation, data collection and analysis were performed by all authors. The first draft of the manuscript was written by MV and all authors commented on previous versions of the manuscript. All authors read and approved the final manuscript.

Availability of data The data have been submitted to the Pangaea data base.

\section{Compliance with ethical standards}

Conflict of interest The authors declare no conflicts of interest.

Open Access This article is licensed under a Creative Commons Attribution 4.0 International License, which permits use, sharing, adaptation, distribution and reproduction in any medium or format, as long as you give appropriate credit to the original author(s) and the source, provide a link to the Creative Commons licence, and indicate if changes were made. The images or other third party material in this article are included in the article's Creative Commons licence, unless indicated otherwise in a credit line to the material. If material is not included in the article's Creative Commons licence and your intended use is not permitted by statutory regulation or exceeds the permitted use, you will need to obtain permission directly from the copyright holder. To view a copy of this licence, visit http://creativecommons.org/licenses/by/4.0/.

\section{References}

Aleksandrov SV (2010) Biological production and eutrophication of Baltic Sea estuarine ecosystems: the Curonian and Vistula Lagoons. Mar Pollut Bull 61:205-210

Aminot A, Kérouel R (2004) Dissolved organic carbon, nitrogen and phosphorus in the N-E Atlantic and the N-W Mediterranean with particular reference to non-refractory fractions and degradation. Deep Sea Res Part I: Oceanogr Res Pap 51:1975-1999. https://doi.org/10.1016/j.dsr.2004. 07.016

Asmala E, Autio R, Kaartokallio H, Pitkänen L, Stedmon C, Thomas D (2013) Bioavailability of riverine dissolved organic matter in three Baltic Sea estuaries and the effect of catchment land use. Biogeosciences 10:6969-6986

Asmala E, Carstensen J, Conley DJ, Slomp CP, Stadmark J, Voss M (2017) Efficiency of the coastal filter: nitrogen and phosphorus removal in the Baltic Sea. Limnol Oceanogr 62:222-238. https://doi.org/10.1002/lno.10644
Asmala E, Haraguchi L, Jakobsen HH, Massicotte P, Carstensen J (2018a) Nutrient availability as major driver of phytoplankton-derived dissolved organic matter transformation in coastal environment. Biogeochemistry 137:93-104. https://doi.org/10.1007/s10533-017-0403-0

Asmala E, Haraguchi L, Markager S, Massicotte P, Riemann B, Staehr PA, Carstensen J (2018b) Eutrophication leads to accumulation of recalcitrant autochthonous organic matter in coastal environment. Glob Biogeochem Cycles. https:// doi.org/10.1029/2017gb005848

Aspila K, Agemian H, Chau A (1976) A semi-automated method for the determination of inorganic, organic and total phosphate in sediments. Analyst 101:187-197

Bartl I, Liskow I, Schulz K, Umlauf L, Voss M (2018) River plume and bottom boundary layer-hotspots for nitrification in a coastal bay? Estuar Coast Shelf Sci 208:70-82. https://doi.org/10.1016/j.ecss.2018.04.023

Bartl I, Hellemann D, Rabouille C, Schulz K, Tallberg P, Hietanen S, Voss M (2019) Particulate organic matter controls benthic microbial $\mathrm{N}$ retention and $\mathrm{N}$ removal in contrasting estuaries of the Baltic Sea. Biogeosciences 16:3543-3564. https://doi.org/10.5194/bg-16-3543-2019

Benitez-Nelson CR (2000) The biogeochemical cycling of phosphorus in marine systems. Earth Sci Rev 51:109-135. https://doi.org/10.1016/S0012-8252(00)00018-0

Benner R, Amon RMW (2015) The size-reactivity continuum of major bioelements in the ocean. Annu Rev Mar Sci 7:185-205. https://doi.org/10.1146/annurev-marine010213-135126

Blomqvist S, Gunnars A, Elmgren R (2004) Why the limiting nutrient differs between temperate coastal seas and freshwater lakes: a matter of salt. Limnol Oceanogr 49:2236-2241

Butman DE, Wilson HF, Barnes RT, Xenopoulos MA, Raymond PA (2015) Increased mobilization of aged carbon to rivers by human disturbance. Nat Geosci 8:112-116. https://doi.org/10.1038/ngeo2322

Carstensen J et al (2020) Factors regulating the coastal nutrient filter in the Baltic Sea. Ambio. https://doi.org/10.1007/ s13280-019-01282-y

Clark LL, Ingall ED, Benner R (1998) Marine phosphorus is selectively remineralized. Nature 393:426. https://doi.org/ 10.1038/30881

Deutsch B, Alling V, Humborg C, Korth F, Mörth C (2012) Tracing inputs of terrestrial high molecular weight dissolved organic matter within the Baltic Sea Ecosystem. Biogeosciences 9:4465-4475

Dippner JW, Bartl I, Chrysagi E, Holtermann P, Kremp A, Thoms F, Voss M (2019) Lagrangian residence time in the Bay of Gdańsk, Baltic Sea. Front Mar Sci. https://doi.org/ 10.3389/fmars.2019.00725

Ferguson A, Eyre B, Gay J (2004) Nutrient cycling in the cubtropical Brunswick Estuary, Australia. Estuaries 27:1-17

Grasshoff K, Kremling K, Erhardt M (1999) Methods of seawater analysis. Wiley-VCH, Weinheim

Gustafsson Ö, Widerlund A, Andersson PS, Ingri J, Roos P, Ledin A (2000) Colloid dynamics and transport of major elements through a boreal river-brackish bay mixing zone. Mar Chem 71:1-21. https://doi.org/10.1016/S03044203(00)00035-9 
Happel E, Bartl I, Voss M, Riemann L (2018) Extensive nitrification and active ammonia oxidizers in two contrasting coastal systems of the Baltic Sea. Environ Microbiol 20:2913-2926. https://doi.org/10.1111/1462-2920.14293

HELCOM (2018) Input of nutrients by the seven biggest rivers in the Baltic Sea region. Baltic Sea Environments Proceedings 163. Helsinki Commission, Helsinki. ISSN 0357-2994

Hellemann D, Tallberg P, Bartl I, Voss M, Hietanen S (2017) Denitrification in an oligotrophic estuary: a delayed sink for riverine nitrate. Mar Ecol Prog Ser 583:63-80

Hoikkala L, Lahtinen T, Perttila M, Lignell R (2012) Seasonal dynamics of dissolved organic matter on a coastal salinity gradient in the northern Baltic Sea. Cont Shelf Res 45:1-14. https://doi.org/10.1016/j.csr.2012.04.008

Hoikkala L, Kortelainen P, Soinne H, Kuosa H (2015) Dissolved organic matter in the Baltic Sea. J Mar Syst 142:47-61. https://doi.org/10.1016/j.jmarsys.2014.10.005

Jones MN (1984) Nitrate reduction by shaking with cadmium. Water Res 18:643-646. https://doi.org/10.1016/00431354(84)90215-X

Koroleff F (1983) Determination of nutrients. In: Grasshoff K, Erhardt M, Kremling K (eds) Methods of seawater analysis. Verlag Chemie, pp 125-139, 162-173

Korth F, Deutsch B, Liskow I, Voss M (2012) Uptake of dissolved organic nitrogen by size-fractionated plankton along a salinity gradient from the North Sea to the Baltic Sea. Biogeochemistry 111:347-360. https://doi.org/10. 1007/s10533-011-9656-1

Letscher RT, Moore JK (2015) Preferential remineralization of dissolved organic phosphorus and non-Redfield DOM dynamics in the global ocean: impacts on marine productivity, nitrogen fixation, and carbon export. Glob Biogeochem Cycles 29:325-340. https://doi.org/10.1002/ 2014gb004904

Letscher RT, Hansell DA, Carlson CA, Lumpkin R, Knapp AN (2013) Dissolved organic nitrogen in the global surface ocean: distribution and Fate. Glob Biogeochem Cycles 27:1-13. https://doi.org/10.1029/2012GB004449

Liss P (1976) Conservative and non-conservative behaviour of dissolved constituents during estuarine mixing. In: Liss JDBAJD (ed) Estuarine chemistry. Academic Press, London, pp 93-130

Lønborg C, Álvarez-Salgado XA (2012) Recycling versus export of bioavailable dissolved organic matter in the coastal ocean and efficiency of the continental shelf pump. Glob Biogeochem Cycles. https://doi.org/10.1029/ 2012gb004353

Lønborg C, Álvarez-Salgado XA, Davidson K, Miller AEJ (2009a) Production of bioavailable and refractory dissolved organic matter by coastal heterotrophic microbial populations. Estuar Coast Shelf Sci 82:682-688. https:// doi.org/10.1016/j.ecss.2009.02.026

Lønborg C, Davidson K, Álvarez-Salgado XA, Miller AEJ (2009b) Bioavailability and bacterial degradation rates of dissolved organic matter in a temperate coastal area during an annual cycle. Mar Chem 113:219-226. https://doi.org/ 10.1016/j.marchem.2009.02.003

Markager S, Stedmon CA, Søndergaard M (2011) Seasonal dynamics and conservative mixing of dissolved organic matter in the temperate eutrophic estuary Horsens Fjord.
Estuar Coast Shelf Sci 92:376-388. https://doi.org/10. 1016/j.ecss.2011.01.014

Martiny AC, Vrugt JA, Lomas MW (2014) Concentrations and ratios of particulate organic carbon, nitrogen, and phosphorus in the global ocean. Sci Data 1:140048. https://doi. org/10.1038/sdata.2014.48

Mattson T, Kortelainen P, Räike A (2005) Export of DOM from boreal catchments: impacts of land use cover and climate. Biogeochemistry 76:10373-10394. https://doi.org/10. 1007/s10533-10005-16897-x

Nausch M, Nausch G (2011) Dissolved phosphorus in the Baltic Sea-occurrence and relevance. J Mar Syst 87:37-46. https://doi.org/10.1016/j.jmarsys.2011.02.022

Pedersen TM, Sand-Jensen K, Markager S, Nielsen SL (2014) Optical changes in a eutrophic estuary during reduced nutrient loadings. Estuar Coasts 37:880-892

Reader HE, Stedmon CA, Kritzberg ES (2014) Seasonal contribution of terrestrial organic matter and biological oxygen demand to the Baltic Sea from three contrasting river catchments. Biogeosciences 11:3409-3419. https://doi. org/10.5194/bg-11-3409-2014

Reader HE, Thoms F, Voss M, Stedmon CA (2019) The influence of sediment-derived dissolved organic matter in the Vistula River Estuary/Gulf of Gdansk. J Geophys Res Biogeosci 124:115-126. https://doi.org/10.1029/ 2018JG004658

Rochelle-Newall EJ, Fisher TR (2002) Production of chromophoric dissolved organic matter fluorescence in marine and estuarine environments: an investigation into the role of phytoplankton. Mar Chem 77:7-21. https://doi.org/10. 1016/S0304-4203(01)00072-X

Romera-Castillo C, Sarmento H, Álvarez-Salgado XA, Gasol JM, Marrasé C (2011) Net production and consumption of fluorescent colored dissolved organic matter by natural bacterial assemblages growing on marine phytoplankton exudates. Appl Environ Microbiol 77:7490-7498. https:// doi.org/10.1128/aem.00200-11

Ruttenberg KC, Sulak DJ (2011) Sorption and desorption of dissolved organic phosphorus onto iron (oxyhydr)oxides in seawater. Geochim Cosmochim Acta 75:4095-4112. https://doi.org/10.1016/j.gca.2010.10.033

Seidel M, Manecki M, Herlemann DPR, Deutsch B, Schulz-Bull D, Jürgens K, Dittmar T (2017) Composition and transformation of dissolved organic matter in the Baltic Sea. Front Earth Sci. https://doi.org/10.3389/feart.2017.00031

Seitzinger SP, Sanders RW (1997) Contribution of dissolved organic nitrogen from rivers to estuarine eutrophication. Mar Ecol Prog Ser 159:1-12

Seitzinger SP, Sanders R, Styles R (2002) Bioavailability of DON from natural and anthropogenic sources to estuarine plankton. Limnol Oceanogr 47:353-366

Soosaar E, Maljutenko I, Uiboupin R, Skudra M, Raudsepp U (2016) River bulge evolution and dynamics in a non-tidal sea-Daugava River plume in the Gulf of Riga, Baltic Sea. Ocean Sci 12:417-432. https://doi.org/10.5194/os-12-4172016

Statistical Yearbook (2006) Statistics Denmark, Copenhagen. Editor Philip Sonne

Stedmon CA, Markager S, Sondergaard M, Vang T, Laubel A, Borch NH, Windelin A (2006) Dissolved organic matter 
(DOM) export to a temperate estuary: seasonal variations and implications of land use. Estuar Coasts 29:388-400

Stepanauskas R, Jörgensen NOG, Eigaard OR, Zvikas A, Tranvik LJ, Leonardson L (2002) Summer inputs of riverine nutrients to the Baltic Sea: bioavailibility and eutrophication relevance. Ecol Monogr 72:579-597

Umgiesser G, Zemlys P, Erturk A, Razinkova-Baziukas A, Měžinė J, Ferrarin C (2016) Seasonal renewal time variability in the Curonian Lagoon caused by atmospheric and hydrographical forcing. Ocean Sci. https://doi.org/10. 5194/os-12-391-2016

UNECE ECfE (2011) Second Assessment of Transboundary Rivers, Lakes and Groundwaters. United Nations, Geneva. http://www.unece.org/env/water/

Voss M, Liskow I, Pastuszak M, Ruess D, Dippner JW (2005) Riverine discharge into a Coastal Bay: a stable isotope study in the Gulf of Gdansk, Baltic Sea. J Mar Syst 57:127-145

Voss M et al (2006) Source identification of nitrate by means of isotopic tracers in the Baltic Sea catchments. Biogeosciences 3:663-676

Vybernaite-Lubiene I, Zilius M, Giordani G, Petkuviene J, Vaiciute D, Bukaveckas PA, Bartoli M (2017) Effect of algal blooms on retention of N, Si and P in Europe's largest coastal lagoon. Estuar Coast Shelf Sci 194:217-228. https://doi.org/10.1016/j.ecss.2017.06.020
Weyhenmeyer GA, Conley DJ (2017) Large differences between carbon and nutrient loss rates along the land to ocean aquatic continuum-implications for energy: nutrient ratios at downstream sites. Limnol Oceanogr 62:S183$\mathrm{S} 193$

Wilson HF, Xenopoulos MA (2009) Effects of agricultural land use on the composition of fluvial dissolved organic matter. Nat Geosci 2:37-41. https://doi.org/10.1038/ngeo391

Zilius $M$ et al (2014) Feedback mechanisms between cyanobacterial blooms, transient hypoxia, and benthic phosphorus regeneration in shallow coastal environments. Estuar Coasts 37:680-694. https://doi.org/10.1007/ s12237-013-9717-x

Zilius M et al (2018) The influence of cyanobacteria blooms on the attenuation of nitrogen throughputs in a Baltic coastal lagoon. Biogeochemistry. https://doi.org/10.1007/s10533018-0508-0

Zweifel UL, Norrman B, Hagström A (1993) Consumption of dissolved organic carbon by marine bacteria and demand for inorganic nutrients. Mar Ecol Prog Ser 101:23-32

Publisher's Note Springer Nature remains neutral with regard to jurisdictional claims in published maps and institutional affiliations. 